\title{
UPAYA MENINGKATKAN KEMAMPUAN PEMECAHAN MASALAH MATEMATIS MELALUI MODEL PEMBELAJARAN KOOPERATIF \\ TEKNIK THINK-PAIR-SHARE SISWA KELAS X SMA SWASTA PAB 5 KLUMPANG TAHUN PELAJARAN 2016/2017
}

\author{
Mardiana \\ STKIP Budidaya Binjai \\ diananst18@yahoo.com
}

\begin{abstract}
ABSTRAK
Penelitian ini bertujuan untuk meningkatkan kemampuan pemecahan masalah dengan model pembelajaran kooperatif teknik Think-Pair-Share (TPS) siswa kelas X SMA Swasta PAB 5 Klumpang tahun pelajaran 2016/2017.Penelitian ini adalah penelitian tindakan kelas (PTK), subjek dalam penelitian ini siswa kelas X-2 SMA Swasta PAB 5 Klumpang tahun pelajaran 2016/2017 sebanyak 40 siswa. Pelaksanaan tindakan dilakukan selama 2 siklus, dimana setiap siklus dilakukan 2 kali pertemuan. Dalam setiap siklus dilakukan 4 tahap yaitu perencanaan (plan), pelaksanaan tindakan (act), observasi (observe), dan refleksi (reflect). Instrumen yang digunakan dalam penelitian ini adalah tes dan lembar observasi. Pada siklus I diperoleh nilai rata-rata siswa 55,5 masih banyak siswa yang belum tuntas pada siklus I, sedangkan nilai rata-rata siswa pada siklus II adalah 75,425 dengan hasil tes yang meningkat dan dapat mencapai ketuntasan belajar siswa. Hasil penelitian menunjukkan bahwa dengan menggunakan model pembelajaran kooperatif teknik think-pair-share dapat meningkatkan kemampuan pemecahan masalah matematika siswa SMA Swasta PAB 5 Klumpang tahun pelajaran 2016/017 pada materi Sistem Persamaan Linear Dua Variabel (SPLDV).

Kata kunci : Model Pembelajaran Kooperatif Teknik Think-Pair-Share
\end{abstract}

\section{PENDAHULUAN}

Pendidikan merupakan kewajiban yang harus kita pelajari dari semenjak lahir. Karena salah satu bentuk perwujudan kebudayaan manusia yang dinamis dan sarat perkembangan. Oleh karena itu, perubahan atau perkembangan pendidikan adalah hal yang memang seharusnya terjadi sejalan dengan perubahan budaya kehidupan. Perubahan dalam arti perbaikan pendidikan pada semua tingkat perlu terus-menerus dilakukan sebagai antisipasi kepentingan masa depan.

Dalam hal ini sekolah sebagai salah satu lembaga pendidikan formal mempunyai tanggung jawab dan wewenang untuk melaksanakan proses pembelajaran. Peserta didik, sebagai komponen inti dalam pendidikan, perlu dibekali dengan kemampuan berpikir logis, analitis, sistematis, kritis dan kreatif agar menjadi sumber daya manusia yang dapat bertahan hidup dalam menghadapi 
kondisi kompetitif. Sikap dan cara berpikir ini dapat dikembangkan melalui pembelajaran matematika.

Matematika memiliki banyak kelebihan dibandingkan ilmu yang lain, dalam matematika kebenaran matematika bersifat koheren, artinya didasarkan pada kebenaran-kebenaran yang telah diterima sebelumnya, dan bersifat universal sesuai dengan semestanya. Matematika memiliki kelebihan dibandingkan dengan bahasa verbal. Matematika mampu mengembangkan bahasa numerik yang memungkinkan kita untuk melakukan pengukuran secara kuantitatif. Dengan belajar matematika siswa diharapkan memiliki kesempatan untuk mengembangkan kemampuan berfikir tingkat tinggi.

Pembelajaran matematika akan menuju arah yang benar dan berhasil apabila mengetahui karakteristik yang dimiliki matematika. Matematika memiliki karakteristik tersendiri baik ditinjau dari aspek kompetensi yang dicapai, maupun dari aspek materi yang dipelajari untuk menunjang tercapainya kompetensi. Ditinjau dari aspek kompetensi yang ingin dicapai, matematika menekankan penguasaan konsep dan algoritma serta keterampilan memecahkan masalah.

Tetapi pada kenyataannya, masih banyak guru yang masih menganut paradigma lama yang dikenal dengan istilah transfer of knowledge dalam pembelajaran matematika masa kini. Paradigma ini beranggapan bahwa siswa merupakan objek atau sasaran belajar, sehingga guru lebih banyak memaksa siswa dengan rumus - rumus atau prosedur - prosedur matematika dan tidak memberikan kesempatan kepada siswa untuk menggunakan penalaran mereka dalam menyelesaikan masalah dan meningkatkan kreativitas siswa. Hal ini tidak sesuai dengan tujuan pembelajaran matematika yang dirumuskan oleh NCTM mengatakan bahwa: "kemampuan pemecahan masalah, kemampuan koneksi dan kemampuan representasi”.

Dari hasil tes diagnostik pada pokok bahasan Sistem Persamaan Linear Dua Variabel (SPLDV) diperoleh informasi bahwa siswa cenderung pasif. Berdasarkan hasil tes siswa pada materi sebelumnya hanya 17,5\% dari 40 siswa yang dapat mencapai nilai KMM yang telah ditetapkan sekolah yaitu 75. Ini dapat dilihat dari salah satu hasil test diagnostik berikut : 


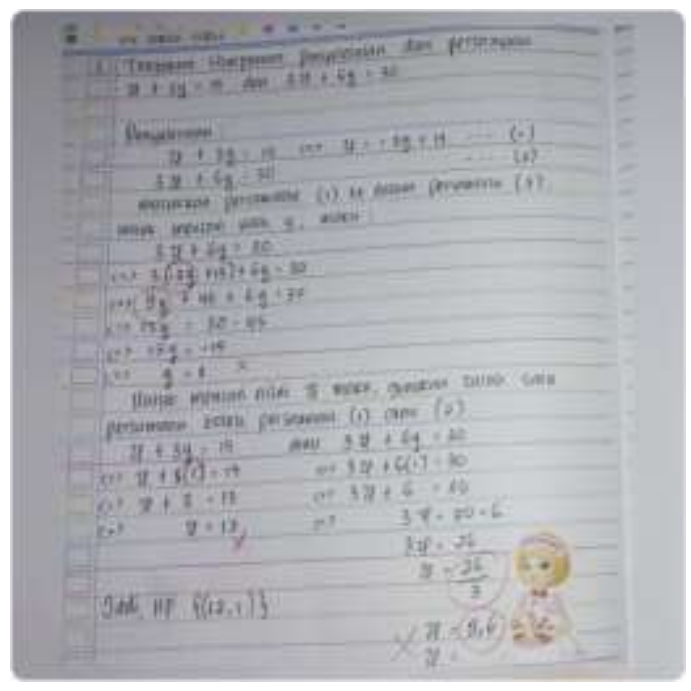

Berdasarkan jawaban siswa tersebut menunjukkan bahwa siswa mengalami kesulitan untuk memahami maksud soal tersebut, merumuskan apa yang diketahui serta yang ditanyakan dari soal tersebut, merencanakan penyelesaian soal tersebut serta proses perhitungan atau strategi penyelesaian dari jawaban yang dibuat siswa kurang sesuai juga siswa tidak memeriksa kembali jawabannya. Sehingga dapat dikatakan kemampuan siswa memecahkan masalah masih sangat rendah.

NCTM mengemukakan bahwa pemecahan masalah merupakan proses menerapkan pengetahuan yang telah diperoleh sebelumnya pada situasi baru dan berbeda. Selain itu NCTM juga mengungkapkan tujuan pengajaran pemecahan masalah secara umum adalah : (1) membangun pengetahuan matematika baru, (2) memecahkan masalah yang muncul dalam matematika dan di dalam kontekskonteks lainnya, (3) menerapkan dan menyesuaikan bermacam strategi yang sesuai untuk memecahkan permasalahan dan (4) memantau dan merefleksikan proses dari pemecahan masalah matematika.

Agar proses pembelajaran memenuhi hal-hal di atas diperlukan suatu kondisi yang memungkinkan siswa aktif, lebih bebas mengemukakan pendapat, 
saling membantu dan berbagi pendapat dengan teman, bersama-sama menyelesaikan masalah untuk memperoleh pengetahuan baru.

Untuk menyiasati permasalahan tersebut, perlu adanya perbaikan dan penyempurnaan kearah sistem pendidikan ataupun dalam hal yang langsung berkaitan dengan praktek pembelajaran. Misalkan dalam menggunakan model pembelajaran. Dalam penelitian ini penulis menggunakan model pembelajaran Kooperatif.

Eggen and Kauchack (dalam Wahyuni) mengemukakan pembelajaran kooperatif merupakan sebuah kelompok strategi pengajaran yang melibatkan siswa bekerja secara kolaborasi untuk mencapai tujuan bersama. Pembelajaran Kooperatif disusun dalam sebuah usaha untuk meningkatkan partisipasi siswa, memfasilitasi siswa dengan pengalaman kepemimpinan serta membuat keputusan dalam kelompok serta memberikan kesempatan kepada siswa untuk berinteraksi dan belajar bersama-sama siswa yang berbeda latar belakang. Johnson dkk menjelaskan bahwa keefektifan pembelajaran kooperatif telah ditegaskan baik oleh riset teoritis maupun demonstrasi.

Model kooperatif tipe Think-Pair-Share (TPS) merupakan jenis pembelajaran kooperatif yang dirancang untuk mempengaruhi pola interaksi siswa. Dimana siswa merasa senang dengan model pembelajaran kooperatif teknik Think-Pair-Share (TPS) karena mereka dapat belajar dengan kelompok secara berpasangan. Meskipun setiap siswa mengalami perubahan yang berbedabeda, namun demikian mereka berusaha memahami dan menyukai pelajaran matematika yang awalnya dianggap pelajaran yang membosankan bagi sebagian siswa. Frank Lyman (dalam Trianto) dari the University of Maryland kemudian menyatakan bahwa : Think-Pair-Share merupakan suatu cara efektif untuk membuat variasi suasana pola diskusi siswa, dengan asumsi bahwa semua diskusi membutuhkan pengaturan untuk mengendalikan kelas secara keseluruhan, dan prosedur yang digunakan dalam TPS lebih banyak waktu berpikir untuk merespon dan saling membantu.

Dari hasil penelitian Bubin menunnjukkan bahwa: "Pembelajaran dengan menggunakan model kooperatif Think-Pair-Share dapat meningkatkan 
kemampuan pemecahan masalah matematis peserta didik”. Dengan demikian masalah yang teridentifikasi dalam penelitian ini adalah banyaknya guru yang menganut paradigma lama dan kemampuan pemecahan masalah matematika siswa masih rendah dengan respon siswa terhadap model pembelajaran kooperatif teknik Think-Pair-Share.

\section{METODE}

Penelitian ini merupakan Penelitian Tindakan Kelas (PTK) atau Classroom Action Research (CAR). Suhardjono (dalam Arikunto) adalah penelitian tindakan (Action Research) yang dilakukan dengan tujuan memperbaiki mutu praktik pembelajaran dikelasnya. PTK berfokus pada kelas atau pada proses belajar mengajar yang terjadi dikelas, bukan pada input kelas (silabus, materi, dan lain-lain) ataupun output (hasil belajar).

Penelitian ini dilakukan di SMA Swasta PAB 5 Klumpang Jalan Besar Klumpang, Kecamatan Hamparan Perak, Kabupaten Deli Serdang. Penelitian dilaksanakan pada kelas X-2 semester ganjil tahun pelajaran 2016/2017. Adapun yang menjadi subjek dalam penelitian ini adalah siswa kelas X-2 SMA Swasta PAB 5 Klumpang yang berjumlah 40 orang.

Sesuai dengan jenis penelitian ini, yaitu Penelitian Tindakan Kelas (PTK), maka penelitian ini memiliki berupa tahapan yang merupakan siklus, terdapat empat tahapan yang lazim dilalui, yaitu perencanaan, pelaksanaan tindakan, observasi, dan refleksi.

Dalam hal ini digunakan instrumen pengumpulan data yaitu tes dan observasi. Tes yang digunakan berupa tes kemampuan pemecahan masalah yang disajikan dalam bentuk tes uraian. Tes yang diberikan mencakup sebelum dan sesudah. Tes sebelum kegiatan pembelajaran berlangsung yang bertujuan untuk melihat kemampuan awal siswa dalam memecahkan masalah, dan sebagai dasar pembentukan kelompok belajar siswa. Sedangkan tes kemampuan memecahkan masalah diberikan setelah kegiatan pembelajaran pada satu siklus selesai, tes ini bertujuan untuk melihat kemampuan pemecahan masalah siswa setelah kegiatan pembelajaran dalam satu siklus terlaksana. Soal-soal yang diberikan kepada 
responden atau sampel terlebih dahulu divalidasikan oleh validator. Observasi adalah pengamatan dan catatan kegiatan pembelajaran yang berlangsung di lapangan.

Dalam perhitungan nilai rata-rata setiap observasi yang dikembangkan oleh Soegito, sebagai berikut:

$$
N R=\frac{\text { Jumlah } \text { skor }}{\text { skor maksimal }} \times 100 \%
$$

Dimana :

$$
N R=\text { Nilai rata-rata }
$$

Kriteria Taraf Keberhasilan Tindakan

\begin{tabular}{|c|c|c|c|}
\hline $\begin{array}{c}\text { Tingkat } \\
\text { Penguasaan }\end{array}$ & $\begin{array}{c}\text { Nilai } \\
\text { Huruf }\end{array}$ & Bobot & Predikat \\
\hline $86-100 \%$ & $\mathrm{~A}$ & 4 & $\begin{array}{c}\text { Sangat } \\
\text { Baik }\end{array}$ \\
\hline $76-85 \%$ & $\mathrm{~B}$ & 3 & Baik \\
\hline $60-75 \%$ & $\mathrm{C}$ & 2 & Cukup \\
\hline $50-59 \%$ & $\mathrm{D}$ & 1 & Kurang \\
\hline$\leq 54 \%$ & $\mathrm{E}$ & 0 & $\begin{array}{c}\text { Sangat } \\
\text { Kurang }\end{array}$ \\
\hline
\end{tabular}

\section{HASIL DAN PEMBAHASAN}

Hasil penelitian untuk kemampuan pemecahan masalah matematika dapat dilihat pada tabel berikut ini :

Rekapitulasi Hasil Tes Kemampuan Pemecahan Masalah

\begin{tabular}{|l|c|c|c|c|}
\hline \multirow{2}{*}{ Pelaksanaan } & \multicolumn{5}{|c|}{ Kategori } \\
\cline { 2 - 5 } & Tuntas & $\begin{array}{c}\text { Persentase } \\
(\%)\end{array}$ & $\begin{array}{c}\text { Tidak } \\
\text { Tuntas }\end{array}$ & $\begin{array}{c}\text { Persentase } \\
(\%)\end{array}$ \\
\hline $\begin{array}{l}\text { Tes } \\
\text { diagnostic }\end{array}$ & 7 & $17,50 \%$ & 33 & $82,50 \%$ \\
\hline Siklus I & 19 & $47,50 \%$ & 21 & $52,50 \%$ \\
\hline Siklus II & 34 & $85 \%$ & 6 & $15 \%$ \\
\hline
\end{tabular}


Hasil observasi pada siklus I yang dilakukan dengan baik yaitu mencapai nilai rata-rata 55,5 dengan kategori baik, dan mengalami peningkatan di siklus II dengan nilai rata-rata 75,425 dengan kategori sangat baik.

Dilihat dari hasil ini, maka dapat disimpulkan bahwa melalui Pembelajaran Kooperatif teknik Think-Pair-Share dapat meningkatkan kemampuan pemecahan masalah matematika siswa kelas X SMA Swasta PAB 5 Klumpang Tahun Pelajaran 2016/2017.

\section{SIMPULAN}

Berdasarkan hasil penelitian dapat disimpulkan bahwa pembelajaran kooperatif teknik think-pair-share dapat meningkatkan kemampuan pemecahan masalah matematika siswa kelas X SMA Swasta PAB 5 Klumpang Tahun Pelajaran 2016/2017. Hal ini dibuktikan dengan peningkatan nilai rata-rata hasil belajar siswa pada setiap siklus. Pada siklus 1 nilai rata-ratanya adalah 55,5, sedangkan nilai rata-rata hasil tes siklus II adalah 75,425.

\section{REFERENSI}

Bubin, Peningkatan Kemampuan Pemecahan Masalah Dan Komunikasi Matematika Siswa Sekolah Menengah Pertama Melalui Model Pembelajaran Kooperatif Tipe Think-Pair-Share (TPS), Jurnal Peluang, Vol. 1, No. 2, April 2013, ISSN: 2302-5158.

Eggen and Kauchack, Peningkatan Kemampuan Pemecahan Masalah Matematis Melalui Model Penerapan Model Pembelajaran Kooperatif Tipe ThinkPair-Share (TPS), Jurnal Pendidikan Matematika Rahmi Wahyuni.2010.

E.Soegito, Kemampuan Dasar Mengajar, (Jakarta: Universitas Terbuka, 2003).

Frank Lyman (dalam Trianto), Peningkatan Kemampuan Pemecahan Masalah Dan Komunikasi Matematika Siswa Sekolah Menengah Pertama Melalui Model Pembelajaran Kooperatif Tipe Think-Pair-Share (TPS), Jurnal Peluang, Vol. 1, No. 2, April 2013, ISSN: 2302-5158.

Johnson dkk, Peningkatan Kemampuan Pemecahan Masalah Matematis Melalui Model Penerapan Model Pembelajaran Kooperatif Tipe Think-Pair-Share (TPS), Jurnal Pendidikan Matematika Rahmi Wahyuni.2010. 
NCTM, Pengaruh Pembelajaran Kooperatif Tipe Core Terhadap Kemampuan Pemecahan Masalah Matematis, Jurnal Pendidikan Matematika ISSN: 2338-1183.

Peningkatan Kemampuan Pemecahan Masalah Dan Komunikasi Matematika Siswa Sekolah Menengah Pertama Melalui Model Pembelajaran Kooperatif Tipe Think-Pair-Share (TPS), Jurnal Peluang, Vol. 1, No. 2, April 2013, ISSN: 2302-5158. 